\title{
From Deviancy to Norm: An Alternative Betrothal Rite in Gyimes ${ }^{1}$
}

\author{
Judit Balatonyi \\ "East-West" ERC Research Group, Institute of Ethnology, RCH, \\ Hungarian Academy of Sciences, Budapest
}

\begin{abstract}
In my writing, I examine the formation and transformation of the betrothal practices of the Roman Catholic Hungarian community of Gyimes based on the results of my fieldwork research from 2005 to 2016. Betrothal came into practice in the 1980s; prior to that, ethnographic sources only mention the ritual occasion of proposal. According to Roman Catholic church norms, the ring could not be worn before the church wedding; only newlyweds were allowed to put it on their finger. For a long time, they used borrowed rings for the blessing of the rings. I explore why it was important for young couples to buy or have their own precious metal wedding rings made, despite regulations that virtually prohibited, but certainly did not support, the pre-wedding wearing of rings. Why did ring wearing and betrothal itself become fashionable? I identify the ideologies and concepts that transformed the earlier rites and views and how they contributed to the popularity of wedding ring sets and companion rings offered by jewelers. I argue that an alternative betrothal rite, the act and ideology of the Csíksomlyó ring exchange, could have greatly contributed to betrothal and ring wearing becoming a common practice in Gyimes. Until the 1990s, this was a strategy adopted by the local community which, similarly to the secular, profane passage into womanhood or emergency baptism, offered an opportunity to exit marginal life situations.
\end{abstract}

Keywords: Double ring ceremony, cult of Virgin Mary, alternative church marriage, invented tradition, Gyimes (Ghimeş, Romania), Csíksomlyó (Șumuleu, Romania) ${ }^{1}$

\footnotetext{
${ }^{1}$ The research leading to these results has received funding from the European Research Council under the European Union's Seventh Framework Programme (FP7/2007-2013)/ERC grant agreement No. 324214 , and it has also been supported by the NTP-NFTÖ-16 project by the Human Capacities Grant Management Office and the Hungarian Ministry of Human Capacities.
} 
In my writing, I examine the formation and transformation of the betrothal practices of the Roman Catholic Hungarian community of Gyimes ${ }^{2}$ based on the results of my fieldwork research from 2005 to 2016. The betrothals of today are unimaginable in Gyimes without the exchange of gold wedding rings or the offering of bridal companion gifts (gold signet rings, necklaces). The rings are worn after the betrothal and are blessed during the Roman Catholic church wedding. That was not always the case though. If we look at the processes a little more broadly, we can see that the description of a $15^{\text {th }}$-century Catholic church ceremony in Hungary already mentions the blessing and exchange of several rings (BÁRTH 2005:127). We also know that wedding rings have been presented in noble betrothals since the $17^{\text {th }}$ century, but the use of wedding rings has only spread among the Hungarian peasantry in the $20^{\text {th }}$ century. Most would only put on a ring, which was typically borrowed, for the wedding ceremony itself (HLATKY 1938). All of this, of course, varied according to local religious traditions and economic conditions. In Gyimes, the exchange and blessing of rings has only become an integral part of the Catholic church ceremony in the last fifty years (since about the 1960s). For a long time, here, too, the rings that were being blessed were borrowed. The borrowed rings had to be returned to the lender at the conclusion of the wedding. According to the relevant Roman Catholic church and community norms, the ring could not be worn before the church wedding; only newlyweds could put it on their finger. Until the 1980s, instead of the betrothal, the ritual event of asking for a girl's hand in marriage is mentioned in the relevant ethnographic notes (ANTAL 1983:146-147), and my conversation partners also emphasized primarily the act of proposal, which was held a few weeks prior to the wedding. Sharing a meal, conversation, and setting the date of the wedding were integral parts of this event. We have records of betrothal gift exchanges up until the 1950s, and the bride would often receive as many as five sets of bed linens. Clothing gifts (local collective noun of these former obligatory gifts) were presented to each other, as well as to the relatives and bridegrooms, most often during the wedding, rarely before the wedding. As a 70-year-old woman recalled in 2005:

\footnotetext{
"It was the fashion, the bride sewing for the groom. She sewed three sets. And for herself, too. Everything she wore was brand new, one was the bridal dress, the second, another bridal dress for when they took off her bun, and one that she wore during the week, it was also Csángó-style, and she sewed for the groomsman ['násznagy'], ${ }^{3}$ for both of the groomsmen, and at that time there were still co-groomsmen ['násztársak'], eight or ten or twelve, their gifts were purchased."
}

\footnotetext{
${ }^{2}$ Until 1820, Gyimes was part of the Transylvanian Principality, from 1940 to 1944 it belonged to the Kingdom of Hungary, and in 1919 it was annexed to Romania. It consists of three settlements: Gyimesközéplok (Lunca de Jos) and Gyimesfelsőlok (Lunca de Sus) in Harghita County, and Gyimesbükk (Ghimeş-Făget) in Bakó County. While the population of Gyimesközéplok and Gyimesfelsőlok is almost completely Hungarian and Roman Catholic, Gyimesbükk is ethnically and religiously heterogeneous. In a broader sense, the areas affected by the migration of the populations of Gyimes (Hárompatak, the Csángó settlements in the Úz valley, and Háromkút [Trei Fântâni, Neamt County]) should also be included here.

${ }^{3}$ The groomsmen (there are usually two or more groomsmen/women invited to the wedding by the bride and groom each) have an advantaged role at the church wedding (witness to the marriage) and the wedding party (they give the largest monetary gifts).

4 Until the 2000s, co-groomsmen were also invited to the wedding, but they were only obliged to give half as many gifts than the groomsmen.
} 
The emergence of ecclesiastical ring exchange was followed in 10-20 years by the betrothal practice of secular ring exchange that preceded, occasionally even substituted the church ritual. These profane betrothals came after the proposal. The suitor usually did the proposing by himself, but his parents and godparents could also accompany him. In the more prominent families, they asked the prospective professional best man (called wedding host, 'lakodalmi gazda' in Gyimes) ${ }^{5}$ to conduct the proposal. In that case, there were several people attending the proposal, and the girl's close relatives were also present. A 70-year-old wedding host told me in 2008:

“(...) The host enters first, followed by the groomsmen, they go to the proposal. The groomsmen go into the thingy, then a couple of friends or relatives, then the parents, and then the bridegroom at the end, and he shuts the door. It was not like (...) they set the table and the girls and womenfolk retreated to a separate room, it was not like this in my time, but it could have been so in the past. And he says, 'Praise the Lord Jesus Christ. Let us give thanks to His Divine Majesty, that His Divine Majesty has preserved and protected us from all sad changes of heart, and all harm to body and soul. We continue to ask the Holy Father to keep His sacred blessing on us, to protect us from evil, and to abandon us not without leaving us the good.' I'm starting to slowly forget it. (...) And then the parents say this and that, and then that they do not mind. Then the bride is usually hidden in another room, we go find her, lead her by a leash on her hand, that is just a formality."

The betrothal was only arranged on a Saturday or Sunday night, "if both parents approved the proposal". The above-mentioned host remembers it like this:

“(...) they bring in the ring in this small basket, and they fill it with flowers. And the host takes it out and he says, "Here are a couple of rings, a gift from my heart and soul, wear them with love and peace, etc." And then the man says, do not cheat on each other, he says that joke, and then he puts the ring on his finger, and if there is an engagement ring, that one too. Because most of the time there is a wedding ring, but in some places, where they are more well-off, they might buy a signet ring as well."

The betrothal complemented the event of the proposal. At first it marked a separate occasion shortly before the wedding, and then it slowly merged with the festive events of the earlier proposal. Occasionally they would already exchange rings at the betrothal: they would exchange casual rings made of silver, bronze or copper coins, while more affluent families bought gold rings from Gypsy goldsmiths. The rings were not worn permanently, and they were only put on right before leaving for the wedding. Then in the early 1990s, instead of the casual, simpler rings, they switched to gold wedding rings and companion rings offered by jewelry shops, and they proudly wore them on their fingers. Betrothal has become a fundamental milestone in wedding customs.

In my thesis, I explore the reasons why despite the cultural-historical antecedents, and the virtually prohibitive, but certainly not supportive, regulations about wearing rings before the wedding it would become important for young couples that they buy or have

5 The best man organizes the wedding; he gives speeches during the festive event, entertains the guests, and also provides practical assistance with the gifts or any emerging complications. 
their own precious metal wedding rings custom-made. Why did ring wearing and betrothal itself and the exchange of rings outside the ecclesiastical context become fashionable at all? What meanings were associated with ring wearing in Gyimes? What may have been the exceptional situations which, overriding the previous rules, required the betrothal and the constant wearing of engagement rings? In my writing, I identify the ideologies and concepts that have transformed the earlier rites and views and how they contributed to the popularity of wedding ring sets and companion rings offered by jewelers.

\section{0-1990: DEVIANT, “ABNORMAL” BETROTHALS - THE TEMPORARY SUBSTITUTION AND REPLACEMENT OF THE CHURCH WEDDING}

First and foremost, we need to clarify that the act of proposal highlighted above was not the only occasion for the announcement of the intention of marriage; eloping was also frequent. This was most commonly done with the mutual agreement of the couple, when the young people who had chosen each other and got along well as lovers could not hope for the parents' consent to their marriage. The elopement was carried out without the knowledge of either set of parents, or at least without the knowledge of the girl's parents, and often despite their physical resistance. However, in the majority of cases, the parents agreed to the marriage eventually. The eloping girl had to dress for the wedding under the most modest of appearances, without a bridal headdress. Because after the elopement she no longer belonged to the girls but neither to the honorable married women, her transient, peripheral situation was made clear through various symbolic methods: until the late 1960s, it was customary for the mother-in-law to put the eloped girl's hair in a bun, a quasi-passage into womanhood, becoming a woman who did not receive the sacrament of matrimony. As a 72-year-old woman remembers this:

\footnotetext{
- (...) Now there is not much of it, but back then it happened that they stole the girl, and then they put her hair in a bun, and for some others they did not even do that, but then, when the time came to go to the priest and get married, that's when they did her hair. There was one that had been a while ago, but it was a long while ago when she eloped, and then they did put her hair in a bun.

- Who did the bunning ${ }^{6}$ [i.e., putting the bride's hair in a bun] at that time?

- This was at the parental house where she was taken. There were some friends in the parental house, and they did the bunning. It was rare that they were bunned, rather, the ones that eloped were bunned eventually, and some others were not even bunned but wore it the same way until the wedding.
}

Young people whose child was conceived or born out of wedlock could also expect to have a more modest wedding. Nevertheless, weddings did not always immediately follow an elopement or the birth of an out-of-wedlock child. Sometimes young couples cohabited for a period of time, unmarried. It was also not unheard of that a big wedding

\footnotetext{
${ }^{6}$ Doing the bride's hair as a women's initiation ritual was also part of the local wedding party until the very beginning of the $21^{\text {st }}$ century.
} 
could not take place for some time due to the unfavorable financial situation of the family or some external limiting circumstances, and in such cases, the young couple was forced into a marginal life situation considered to be deviant, which neither the community, nor the young couple or their close family found to be a comforting state.

The betrothal rite at the nearby Virgin Mary Shrine of Csíksomlyó ${ }^{7}$ (local term Csíksomlyó betrothal or Csíksomlyó ring exchange), an alternative rite of ring exchange, offered a temporary solution to these marginal life situations. During the Csíksomlyó rite, the young couple attended mass (either in Gyimes or in Csíksomlyó), then exchanged rings while kneeling at the feet of the statue of the Virgin Mary in the Shrine of Csíksomlyó. Prayers and supplications were part of the rite, as were the accompanying promise, oath and vow to one another. Some would kiss Mary's feet, touch the statue with their rings, and sometimes even money would be placed in the slot under the statue. Quoting from the recollections of a 35-year-old woman from 2008:

- In 95, we went to Somlyó [i.e., Csíksomlyó], that's when I came here to be married. We went to the Somlyó pilgrimage, and then they came out, the mass ended and all.

- Then you went to the pilgrimage site, and you put on the rings after the mass?

- (...) We went up, kissed Mary's feet, and X and I put on the rings.

- And did you say something to each other at that time, or were you just silent?

- We were silent, we said nothing, there were so many people there.

- And you prayed silently?

- Yes.

- You prayed to the Virgin Mother?

- Yes, we even knelt down.

- It must have been very nice.

- Indeed! That's when we put them on, in 95, that's when I first went to Csíksomlyó.

An important and special feature of the rite is the precious metal wedding ring that has been blessed, and which, as I have already pointed out, was not very typical of other types of betrothals until the late nineties, as exchanging and wearing rings was only permitted after the church wedding. The ring was officially blessed by the priest only during the church wedding ceremony. Before the Csíksomlyó betrothals, the blessing of the rings was in many cases carried out by the priest indirectly: typically, the young couple would hide the rings in the branches of their Christmas tree, so when the priest came to bless the family's Christmas tree during the annual house blessing - at Epiphany - he would also bless the rings. As a 35-year-old woman told me in 2008:

- It was said that we should not wear the rings before the wedding and all, and so it was that we put them on top of the Christmas tree when the priest came. And the rosary, too, because I could not go to the church to have the priest bless it. (...) When he came to bless the house, he blessed it.

- So the rings are also taken in to be blessed?

${ }^{7}$ In Csíksomlyó [Şumuleu Ciuc], about 19 miles from Gyimes, there is an extremely important Roman Catholic pilgrimage site which attracts numerous Hungarian pilgrims every Pentecost. Csíksomlyó is a neighborhood of Csíkszereda (Miercurea Ciuc, Harghita County, Romania). 
- No, he blesses them when we get married.

- So was it already blessed then?

- Yes, we put them on the Christmas tree, but we did not tell the priest, he did not know, had no clue.

According to my conversation partners, the first Csíksomlyó betrothal may have been arranged in the eighties by a (Romanian or Hungarian) couple from Háromkút, after which more and more couples from Háromkút and Gyimes were getting betrothed in Csíksomlyó. They found the ritual to be so simple yet great, so beautiful and effective that more and more young couples from Gyimes that were cohabiting and/or had an outof-wedlock child tried to legitimize their relationship by getting betrothed according to the script of the rite they came to know. The rite also became a strategy adopted by the community that, similarly to the secular "passage into womanhood" or the "emergency baptism" of nonviable fetuses not carried out by priests, provided an opportunity outside of the church for exiting a deviant state. As Eszter Csonka-Takács pointed out in connection with the secular initiation of women who have recently given birth: through a private rite of going around a sacred object, like a roadside cross, the unmarried mother could be exonerated, purified, and enter into a new social status (CsONKA-TAKács 2008:140-141). Dániel Bárth mentions several examples of women's initiations that substitute official church rituals, and, like Csonka-Takács, he also attributes the existence and communal acceptance of these "paraliturgical" customs to taboos of impurity, as well as to the individual and community interests in lifting these taboos (BÁRTH: 2007:91). To this day, the aforementioned emergency baptism functions in Gyimes as a rite that substitutes the official church ritual. The rite can be done by all Christians. Its essential accessories: the holy water or ordinary water, perhaps saliva, used for the blessing, and the text of the baptismal formula.

Like the secular passage into womanhood, the Csíksomlyó ring exchange is about seeking out a sacred place or sacred object (the statue at the Csíksomlyó church), usually on a feast day (most often at Pentecost), where they essentially perform an analogy of a church wedding with a roughly defined series of rites; without the presence of a priest and witnesses, they confer on each other the sacrament of matrimony. Thus, the most important motivation of the earliest Csíksomlyó betrothals was to ensure the legitimate and consecrated nature of the partnership and its personal and community acceptance.

The Csíksomlyó ring exchange did not permanently replace the church wedding; it only temporarily replaced it, sometimes for an extended period. Csíksomlyó ring exchanges were often followed by long engagements. Cohabiting couples expecting a baby wanted to legitimize their illegitimate relationship through this rite. Wearing a ring changed the social status of unmarried mothers, lifting them out of a role stigmatized as deviant, while in the case of men, it symbolized the responsibility of their roles as a "pater". In "A Real Man's Ring: Gender and the Invention of Tradition" (Howard 2003), Vicki Howard also emphasizes the divergent social gender interpretations of the wedding ring. In the USA, the groom's ring became popular in the post-WWII era when wedding, marriage and the "tamed man" became symbols of prosperity, capitalism and national stability. The groom's ring also symbolized new kinds of obligations. Women interpreted the wedding ring set differently, and many maidens were wearing a wedding ring because it represented a kind of expected social status (HowARD 2003). In Gyimes, the social 
representation of betrothal (people talking about it) and wearing the wedding ring also communicated to the community that when their economic situation or family problems are settled, they will indeed marry. In his work, "Premarital Prediction of Marital Quality or Breakup", Thomas B. Holman argues that the success or failure of marriages is related to the positive or negative nature of communication between the married parties. He also points out that the quality of communication between couples before marriage predicts the success of the marriage. Referring to Robert N. Bellah's 1985 research, he considers contemporary marriages a metaphor for communication (CARROLL - HOLMAN 2001:142). In terms of communication processes between couples, the Somlyó ring exchange was also essential in Gyimes because it counted - and still counts today - as a sort of "couples therapy". After all, young couples are clarifying their relationship and their prospects under ritual conditions. The wedding ring is meant to represent a legitimate, communityrecognized relationship and indicates the upcoming marriage.

\section{ADAPTABLE PATTERNS - ANALOGIES OF ROMAN CATHOLIC AND ORTHODOX CHURCH WEDDINGS, CSÍKSOMLYÓ PILGRIMAGE, MARIAN DEVOTION}

The most important feature of the Csíksomlyó ring exchange is that the couples tried to confer on each other a sacrament similar to marriage. But how and from what patterns was the betrothal rite of Csíksomlyó created? I assume it is not merely a matter of imitating the Roman Catholic church wedding or of the spontaneous expansion of "normal" betrothals, but rather we are looking at much more complex relationships. I identify here all the possible adaptable patterns and parallels that could have determined, ideologically and/or at the level of practices and rites, the concept and creation of the tradition of the Csíksomlyó ring exchange.

During the ring exchange, the elements of the Roman Catholic wedding ceremony that are considered to be most important are being utilized and placed in a new context. If we take the most important ritual elements of the ring exchange (attending mass; certain lines of the marriage vows, the declaration of intention of marriage; ring exchange while kneeling at Mary's feet; prayer/supplication to the Virgin Mary of Csíksomlyó; monetary or flower offerings to the Virgin Mother), and compare them with the liturgy of Roman Catholic church wedding ceremonies, we can discover striking similarities. In the Gyimes wedding ceremony, among other things, the couple proclaims their intention of marriage, the "ancient Hungarian custom" of sworn promise is made, and the priest blesses the rings, which the husband and wife then put on each other's fingers as a sign of love and fidelity. After the blessing of the marriage, the newlyweds bring white flowers to the altar of Mary and pray for a happy marriage, asking for Mary's help. Here I must note that after the wedding, Gyimes brides often hid the lucky coin concealed in their shoes behind a representation of Mary: it may have been a public sculpture, or even in the private sphere, a painting of Mary on a wall. The offering of flowers and prayers to Mary was followed by a common prayer, after which the priest blessed the newlywed couple.

According to the logic of the people of Gyimes, through these betrothal rites, they hope for the blessing of the Virgin Mary (and her statue at Csíksomlyó), who had an important 
role in their daily religious life, for which there is no possibility (yet) within the framework of the Roman Catholic Church. By the way, in the 2006 Hungarian edition of the "Order of the Marriage Ceremony (Roman Ritual)", there is already a reference to the ceremony of the blessing of the betrothed couple. The diocesan priest of Vác said the rite should be conducted so that it is clear: it is not a marriage ceremony or some kind of anticipation of it, "for we cannot create the semblance of the church blessing pre-marital cohabitation. For this reason, according to the rules, it never can be done during the Holy Mass" (KÁPOSZTÁs 2008: 64). In Gyimes, there has not (yet) been such a local ecclesiastical initiative, young couples may only request a mass after their betrothal, but the function of the betrothal rite of Csíksomlyó best corresponds to this ecclesiastical ceremony, with the difference that in Gyimes this is done bypassing the local church. The ritualistic features of Marian devotion in Gyimes are highlighted in the script of the Csíksomlyó betrothal: the prayers, the gestures of asking for a blessing, help and absolution, and the various offerings to Mary are present in both festive and everyday religious practices (KAJÁRI 2008; PóCS 2008). I emphasize the particular veneration of the Csíksomlyó statue in Gyimes, including the intent to meet Mary, to touch the statue, the offerings, the act of asking for help, and the miraculous, healing power attributed to the statue. I mentioned the act of touching the statue with the wedding rings among the associated elements of the Csíksomlyó betrothal, which can be paralleled with other magic-religious acts related to the statue practiced by the Csángó of Gyimes: for example, when they arrive at the Csíksomlyó shrine, they try to wipe the statue with their handkerchief or a piece of clothing (not just during feast days). In the past few years, due to the preservation of the sculpture, two girls in a "Székely/ Sekler outfit" have been tasked with the touching during the Csíksomlyó pilgrimage. The handkerchief that touched the statue is preserved and cherished, and used for healing if in need. Special powers are also attributed to the rings that came in contact with the statue, which is further reinforced by the ecclesiastical blessing. The wedding ring protects the betrothed and newlyweds and their relationship, but it can also be used for removing a curse. Csíksomlyó church weddings (of friends, acquaintances or relatives), of which the statue of the Virgin Mary is often a central element (through prayers, asking for blessings, offering money and flowers), may also have served as examples. Essentially, we may be talking about an extension of a religious aspect of the Csíksomlyó pilgrimage, ${ }^{8}$ a new motivation for visiting the statue of Our Lady.

Due to the origins of the Csíksomlyó betrothal in Háromkút and the long-term coexistence and interaction between Roman Catholics, Greek Catholics and Orthodox Romanians and Hungarians (as well as Gyimes, and primarily the Orthodox minority of Gyimesbükk), we must also consider the possible effects and parallels of Orthodox and Greek Catholic betrothal and wedding liturgies. Of particular interest to us is the ring ceremony of the Orthodox and Greek Catholic wedding liturgy, which involves

\footnotetext{
${ }^{8}$ Here I just note the most important comprehensive works: Tamás Mohay's work on the Pilgrimage in Csiksomlyó addresses the research history of the topics in question (MoHAY 2009), Sándor Bálint's work surveys his research on the St Mary Shrine in Szeged-Alsóváros (BÁLINT 1983).László Székely's book, "Devotion in Csík", is important for the St Mary cult of the Székely people (Székely 1995).In terms of my subject, Krisztina Frauhammer's 1999 book, "Letters to Mary" (Frauhammer 1999) are important, as well as her 2009 doctoral dissertation, in which she undertook a comparative analysis of the guest books of Hungarian shrines and specifically analyzed the prayers written to Mary regarding love and partnership (FraUHAMmER 2009).
} 
not only the blessing and exchange of rings, but also a complex betrothal ceremony. Because of the similarity of Greek Catholic and Orthodox betrothal rites, I mention primarily the Orthodox betrothal. The exchange of rings is technically not even part of the Orthodox wedding ceremony, but a separate complex complex church betrothal ceremony (Romanian term 'logodna'), which in Gyimes, up until the 2000s, may have preceded the church wedding ('cununie') by a month or two. Ecclesiastical betrothals are already mentioned by $8^{\text {th }}-12^{\text {th }}$-century sources (GAVRILĂ 2004:119-148; CANONUL ORTODOXIEI 2008:909-1032; VANCA 1998:82-98). Orthodox betrothal is today an integral, independent unit of the church wedding. The newer church wedding is a mixture of these two previously separate rites (betrothal and actual wedding). In Orthodox weddings in Gyimes, members of the wedding party - bridegroom, bride, wedding host, and priest - meet at the back of the church. During the betrothal ceremony, the priest traces the sign of the cross in the air over the young couple's head three times, thereby "betrothing" them to each other, then touches the rings to their foreheads. They exchange rings three times, the bride's ring is put on the groom's finger and vice versa. The rings symbolize the betrothal itself. After the exchange of rings, the coronation ceremony the actual wedding - begins. The priest and the betrothed go to a small table. Before the 2000s, Orthodox betrothal could also take place in a family circle (profane, civil betrothal ceremony, 'logodna civilă'), which, although not mandatory, was in most cases followed by the church blessing and confirmation. The betrothal ceremony was held in the home of one of the betrothed's parents over a family lunch or supper. The festive betrothal was not a preparation for the marriage but the genuine commencement of it. In many cases, ecclesiastical betrothals were regarded as a temporary substitute for the wedding. For parents, young couples and the community, it also meant the anticipation of marriage, a firm promise to marry. In many cases, the young couple moved in together after the betrothal. ${ }^{9}$ The ecclesiastical limitation of the ecclesiastical betrothal preceding the Orthodox church wedding by months is interesting: merging the betrothal with the wedding. Local priests, and Orthodox churches in Romania in general, wanted to prevent church weddings from being postponed and quasi-substituted by sanctioning the betrothals and legalizing the status of the betrothed. Many considered the ecclesiastical betrothals preceding the church wedding as the legalization of cohabitaion ('legalizare a concubinajului'), which is in no way permissible. In any case, the ecclesiastical and secular rites of the Orthodox betrothal ceremony, and especially the notion that the exchange of rings and wearing of rings is the precursor and temporary substitution for the church wedding, may, in my view, have influenced the rite organization and the ideology and interpretations of the Csíksomlyó betrothals. The marriage-substituting, precursory role of the Csíksomlyó betrothal can be definitely paralleled with the similar function of Orthodox and Greek Catholic ecclesiastical betrothals.

\footnotetext{
${ }^{9}$ Until the publication of the new Civil Code (Volume II, paragraphs 266-270), which entered into force on October 1, 2011 (and which also affects the legal aspects of the engagement), the obligation of the betrothed couple to marry was only moral in nature, not legal, both civic and in ecclesiastical terms.
} 


\section{0-2016: FROM DEVIANCE TO NORM - NEW TENDENCIES IN THE CSÍKSOMLYÓ BETROTHAL}

From the late 1990s, early 2000s, the elimination of a deviant state and the pursuit of community acceptance slowly faded from among the motivations of the Csíksomlyó ring exchange. The formerly deviant, "abnormal" nature of the rite as a wedding substitution or replacement for a wedding was clearly de-emphasized. All this was related to the slow change in local opinions on premarital cohabitation. Because even though the Church continues to urge expeditious weddings, cohabitation and premarital childbearing are condemned by local priest to a much lesser extent. Indeed, Catholic priests in Gyimes emphasize that the conception and birth of a child in itself cannot be a reason for marriage. The bride's pregnancy may actually be a barrier to marriage because of the risk that the parties are not getting married for love but rather for the child's sake, especially when it comes to a pregnancy following a short acquaintance. As one of the priests said in 2011:

When they come in, I ask, of course, is there a reason for the wedding? And then they say they are expecting a baby. And I'll ask, is that why you are getting married? Because it could even be an obstacle, for if she feels compelled, the boy's parents coming with honor this, honor that (...) if we look at it that way, it's a compulsion, that cannot be a reason for marriage. I had one such case. (...) In another case, the girl became so very fond of that boy that she would have done anything she could to keep him. (...) So she got pregnant, and of course the boy married her. Then of course I heard from the faithful that there was no child, but there could still be, I said, and they said, Father, there never will be. Because she did not want one, she just wanted the boy to marry her. Well, what can be done in such a case? The interest; and of course she's surprised later that things are not going well. (...)

At the same time, the Csíksomlyó rite remains more overrepresented among those who had somehow violated the community standards, cohabited or had a child before marriage, and it was therefore not appropriate to organize a larger, more festive betrothal. In such cases, the simpler, more modest Csíksomlyó betrothal is considered as a kind of sanction. I asked a groom's mother in 2007:

- So you did not even participate in the betrothal?

- No, I was not there, only they were. There was no big ceremony. (...) The older one had it like that, too, my older son, his bride got pregnant, too, and this one is pregnant, too, she is not so big, but if she is pregnant, they say this is what's appropriate. So this is what we do.

In this context, the new Csíksomlyó betrothals are often the beginning of shorter betrothals. A 45-year-old woman explained this in 2008 as follows:

- And why would that be [i.e., why are Csíksomlyó betrothals arranged]?

$-(. .$.$) because whoever puts on a ring is already sworn to be preparing for the wedding, because$ it is not a long-term betrothal, not that they will be getting married in a year, but in three or four months. They put on a ring when they count on getting married ... But they usually betroth each other when they know they will be getting married. In the old days, there were some that went on for a long time and in the meantime they broke up and the rings were returned. 
Between 2000 and 2010, the Csíksomlyó ring exchange became an integral part of local betrothal practices. It had several different narratives and interpretations attached to it. Like, for example, the rhetorical strategy by which young couples distinguished their own, newer Somlyó betrothals from the previous versions of it as a "marriage substitute". The new betrothals were considered modern and fashionable and fundamentally beautiful. Another characteristic was ignoring the history of the Csíksomlyó rite, i.e., thinking that it was a completely newly created tradition with no precedent. Some of my conversation partners even assumed the rite had its origins in Hungary. It was also common among rite organizers to assume a kind of cultural continuity, and referring to their own Somlyó betrothal as a traditional "Csángó" betrothal: "I am preserving the old Csángó traditions". In addition to highlighting the old or modern features of the rite, the practical, economic and religious motivations of rite organization were often emphasized. According to my conversation partners from Gyimes, young couples are now getting betrothed in Csíksomlyó because it is an important cost-saving aspect, as is asking for a blessing for the betrothal. When choosing the Csíksomlyó betrothal, "no big fuss" is required, thus saving costs, and they are also putting their "trust in the Virgin Mary of Csíksomlyó".

Here are a few examples of the newer, highly fashionable Csíksomlyó betrothals between 2000 and 2010. During a 2006 Csíksomlyó betrothal, the young couple put the rings on in front of "Mary of Csíksomlyó", and after the ring exchange, they shared a supper in the presence of parents, siblings and grandparents. The young couple decided jointly that they would like such a betrothal because, as they said, they used visit Csíksomlyó often to ask for "Mary's help". The rite took place as follows. At home, they attended mass in the morning because they did not know the order of masses in Csíksomlyó. Then, as they told me:

$-(\ldots)$ your betrothal, how was that for you?

- Well, it was at Christmas, in our family home. And it was just that we went to Somlyó, we put on the rings in front of Mary, then there was a supper in the evening, with only my parents, her parents, and the siblings, and my grandparents.

- And who had the idea to have the betrothal in Csíksomlyó?

- Both of us together. (...) we used to go out there and ask for Her help.

The young couple traveled to Csíksomlyó by bus, where they exchanged rings while kneeling in front of the statue of Mary in the shrine. During the ring exchange, "they said something to each other, something simple, a promise: "so God help me, Our Lady the Blessed Virgin Mary, that I love you, X, and I am marrying you for love ....". During the vow, they touched the feet of the statue. They also decided on the Somlyo betrothal so they would not have to spend much on the betrothal. A 42-year-old conversation partner of mine was present at her daughter's Csíksomlyó betrothal on February 14, 2008. The bride was already living with her fiancé in Csíkszereda before the betrothal. Kneeling before the statue, the young couple put on their rings, which they kissed before exchanging them, and accompanied them by some words: "Do you want to be my wife? Do you accept to this ring?" "Wear this ring as a symbol of my love and fidelity, in the name of the Father, the Son, and the Holy Spirit." The parents and the younger, unmarried siblings were present, and the ring exchange was followed by a dinner at the 
groom's family. It was the wish of the young couple to get engaged in Csíksomlyó and on Valentine's Day, on the day of lovers.

I also mention a 2008 ring exchange that practically never took place, but family members and neighbors nevertheless referred to it as a Csíksomlyó betrothal. The young couple set their betrothal date for the time of the pilgrimage in Csíksomlyó. According to the 21-year-old bride, they planned the betrothal in Csíksomlyó because they did not want anything big so they would not have to make preparations. The bride's early pregnancy was also a factor in the simple betrothal. Eventually, it did not happen because of the Pentecostal crowds:

- Well, the betrothal was nothing much, we did not want anything bigger, as it was the Pentecostal pilgrimage [to Csíksomlyó], and we thought we would just put on the rings there. There were a lot of people, and we could not go up to Mary, but that's where we wanted to do it, so we did not put them on that Saturday, and on Sunday I could not go in, it was very warm. So then, on Monday, we just put them on here at home, the two of us.

- And why did you decide that you wanted it to be just the two of you?

- We did not want a big fuss.

Talk of the rite was confined to the planned but unrealized rite. Relatives who knew about the failed betrothal attempt considered the intention of the young couple to be more important, and despite the fact that they did not exchange rings at their chosen site, they still referred to it as a Csíksomlyó ring exchange because the young couple went to the holy place on the holy day, and the betrothal took place shortly after their stay in Csíksomlyó, in the bride's home, "between the two of them". A newlywed girl from Bükkhavas, according to the bride's sister-in-law, also had a Csíksomlyó ring exchange, and the bride's 51-year-old mother spoke of a Csíksomlyó betrothal. She was not even aware that the young couple did not exchange rings there but at home:

- Well, they went to the Csíksomlyó pilgrimage, took the parcels with the stuff for under the cross, their clothes, and the food. And then they went up to Mary and there they put on the rings there.

- And did they say something?

- Well, they prayed silently.

- And nothing else happened after the ring exchange was done?

- No.

- Did they not plan a dinner or something?

- Well, we did not plan one because our other daughter did not have one, so we did not do it for her either.

I heard news of a number of Csíksomlyó betrothals up until the early 2010s; it was very popular among young people. By now, the rite has slowly become only one of the many betrothal rites that one can opt for.

There are two major types of betrothals distinguished in Gyimes: larger ones that take place in the presence of groomsmen, and smaller ceremonies. Smaller betrothals are further divided into two more types: family and individual betrothals. The rite of the Csíksomlyó ring exchanges falls into the latter two subgroups. The shift away from it 
is mostly due to the fact that lately they are more likely to prefer bigger betrothals with more participants. According to the latest opinions, the Csíksomlyó rite is not the most perfect option because the most important actors of the rite are missing: the family, the relatives, the groomsmen, all of whom bear witness to the betrothal and also bestow their blessing on it. With regard to individual betrothal, the objection is that the young couple betroth each other in secret to bypass their parents, without asking for their parents' permission or blessing, thus sort of acting behind their backs. This opinion was shared in 2011 by one of the priests of Gyimesközéplok:

(...) They go to the statue of Mary in Csíksomlyó. There are some that tell me this, because of our relationship. They are more confiding, open, and they used to say they do not want big expenses. Although, although both are correct. There is an official formula in which the godparents, the groomsmen come and there is a proposal. And there are also cases where the parents do not know about it, and that is uncomfortable. In the old days, they would elope, if the boy was a coward. If he dared not say what his intention was. And then they took a liter of pálinka and went to appease the father. But it would still be the right thing, for the family to be there, for a small celebration.

In a 50-year-old woman's opinion from 2014:

- But I do not condone it. I mean, it's good to put on a ring, but a betrothal is a nice thing, at least with the family. But I think it is good that we are devoted to the Virgin Mother, Our Lady, and that we adore her, but a parent is a parent, and why should the parent not be present. Isn't it so? (...)

And the parent deserves as much. (...)

- And those who put them on there are doing it in secret?

- No, they just do not want such a big fuss.

- So there would not be a big expense?

- This is not so much either [i.e., a larger betrothal], because there were not so many of us, it was not such a big gathering, just the groomsmen, and the siblings, and the parents.

The other common criticism of the Csíksomlyó betrothal is about hypocrisy and "sanctimoniousness", i.e., that the participants of the rite create the appearance of religiousness by arranging for a Somlyó betrothal. All this is not directed at specific persons, but rather at the institution of the Csíksomlyó betrothal. According to a 24-yearold man:

- Well, that's just putting on airs. Individual grandstanding.

- So, then, is this a religious thing?

- It's not religion. They are holier-than-thou. Comes out of the church and trash already coming

out of his mouth. Ah, sorry, sycophants, adulators. Going up to Mary.

A 60-year-old man thought likewise:

And they would hold the wedding, and in about a week or two, or after a month they are getting divorced because they do not like each other. Well, then why go to the Virgin Mary? It does not 
help anything, nothing. Be honest in your soul, not just to show off where I put on the ring or something like that. It does not matter if I'm putting on the ring in front of the Virgin Mother or where I put on that fucking ring, but it must last a lifetime.

So, it seems that Somlyó betrothals are no longer able to fit the ever-changing local betrothal practices or the local norms and ideas regarding betrothal. While in the past, until the 2010s, the fact that the rite was simple and could be carried out with less financial resources was a positive attribute, nowadays this is considered more of a disadvantage. Instead of the smaller, less public Somlyó betrothals, they now prefer larger, more showy betrothals.

\section{CONCLUSION}

In practice, the Csíksomlyó ring exchanges and betrothals of the 1970s-1980s were occasions for ring exchanges outside of the church and preceding the church wedding where young couples exchanged gold or silver wedding rings bought solely for this purpose and wore the rings after the betrothal. In Gyimes, the act and ideology of the Csíksomlyó ring exchange may have greatly contributed to betrothal and the wearing of engagement rings becoming customary. Until the 1990s, the rite was a strategy adopted by the local community which, similarly to the secular, profane passage into womanhood or emergency baptism, offered an opportunity to exit marginal life situations. Young couples performed a roughly defined series of rites as an analogy of a Roman Catholic church wedding and presumably following the ideologies of Orthodox betrothals, which was a sort of stopgap remedy. From the early 2000s, it became an integral part of betrothal practices. Today, this rite is interpreted in a completely different way. We can speak of a kind of fashion or norm following. After its heyday between 2000 and 2010, the rite has slowly lost ground again, becoming but one of the options among small-scale betrothals. Lately, bigger, more festive betrothals are preferred. The Csíksomlyó betrothal is also an example of invented traditions, in the course of which a betrothal tradition has been created by reinterpreting an earlier cultural pattern and adapting certain elements of Marian devotion, pilgrimage, and weddings to meet contemporary expectations and needs.

\section{REFERENCES CITED}

ANTAL, Imre

1983 Udvarlás és leánykérés Gyimesben [Courtship and Proposal in Gyimes]. In BÁLINT, Sándor Kós, Károly (ed.) Népismereti Dolgozatok, 141-149. Kolozsvár: Kriterion.

1944 Boldogasszony vendégségében [Visiting with the Blessed Virgin]. Budapest: Veritas Könyvkiadó.

1977 Ünnepi kalendárium. A Mária-ünnepek és jelesebb napok a hazai és középeurópai hagyományvilágból [Holiday Calendar. Marian Feast Days and Other Significant Holidays in Local and Central European Traditions]. I-II. Budapest: Szent István Társulat. 
1983 Szeged-Alsóváros. Templom és társadalom [Szeged-Alsóváros. Church and BÁRTH, Dániel Society]. Budapest: Szent István Társulat.

2005 Esküvő, keresztelö, avatás. Egyház és népi kultúra a kora újkori Magyarországon [Wedding, Christening, Initiation. The Church and Folk Culture in Early Modern Hungary]. Budapest: MTA-ELTE Folklór Szövegelemzési Kutatócsoport.

Canonul Ortodoxiei I. (Canonul apostolic al primelor secole)

2008 Sibiu: Deisis - Stavropoleos. 909-1032.

FrauHAMmER, Krisztina

1999 Levelek Máriához. A máriakálnoki kegyhely vendégkönyve [Letters to Mary. The Guest Book of the Shrine in Máriakálnok]. (Devotio Hungarorum 6.) Szeged: JATE Néprajzi Tanszék.

2009 Szemben a feledéssel. Magyar kegyhelyek vendégkönyveinek összehasonlitó elemzés [The Opposite of Oblivion. A Comparative Analysis of the Guest Books of Hungarian Shrines]. (Kézirat, doktori disszertáció, Néprajz és Kulturális Antropológiai Tudományok Doktori Program, Európai Etnológia Doktori Program) http://doktori.btk.elte.hu/folk/nagynefrauhammerkrisztina/ diss.pdf (accessed March 26, 2017)

GAVRILĂ, Vasile

2004 Cununia viaţă întru impărăţie. Bucureşti: Editura Fundaţia Tradiţia Românească.

HLATKY, Mária

1938 A magyar gyürü [The Hungarian Ring]. Budapest: Pallas Kiadó.

HOWARD, Vicki

2003 A 'Real Man's Ring': Gender and the Invention of Tradition. Journal of Social History XXXVI(4):837-856.

KAJÁRI, Gabriella

2008 Az imaéletbe való belenevelődés Gyimesközéplokon [Inculcating Children with Prayer in Lunca de Jos]. In Pócs, Éva (ed.) "Vannak csodák, csak észre kell venni.” Helyi vallás, néphit és vallásos folklór, 197-237. Budapest: L'Harmattan Kiadó.

KÁposzTÁs, Béla

2008 Készület és ünneplés. A jegyeskurzus mint a házasságkötés ünneplésének minőségét alapozó és elmélyítő lelkipásztori alkalom [Preparation and Celebration. The Marriage Preparation Course as a Foundation of a Quality and Meaningful Wedding Celebration]. Preconia 3:61-74.

MoHAY, Tamás

2009 A csíksomlyói pünkösdi búcsújárás. Történet, eredet, hagyomány [The Pentecostal Pilgrimage in Csíksomlyó. History, Origin, Tradition]. Budapest: L'Harmattan. 
Pócs, Éva

2008 "Rajtunk is történt csoda." Beszélgetések és elbeszélések a természetfelettiről ["We Witnessed a Miracle." Conversations and Narratives about the Supernatural]. In Pócs, Éva (ed.) "Vannak csodák, csak észre kell venni." Helyi vallás, néphit és vallásos folklór, 299-374. Budapest: L’Harmattan Kiadó.

SzÉKELY, László

1997 Csíki áhitat. A csíki székelyek vallási néprajza [Devotion in Csík. The Religious Ethnography of Székelys in Csík]. Budapest: Szent István Társulat.

VANCA, Dumitru

1998 "Cununia" în secolul XVII în Transilvania. Consideraţii pe marginea Molitfelnicului de la Bălgrad (1689). Credinţa Ortodoxă IV(3-4):82-98.

Judit Balatonyi received her PhD degree from the Interdisciplinary PhD School, Program for European Ethnology and Cultural Anthropology (University of Pécs, Hungary). She has been working as an assistant lecturer at the Department of Ethnography and Cultural Anthropology and as a guest lecturer at the Institute of Education, Department of Romany Studies and Sociology of Education (University of Pécs). Her major research interests are: anthropology of ritual and religion; anthropology of love and friendship; culture and society of Hungarian and Romanian people of Gyimes; anthropology of Gypsies. She participated in several Hungarian and national research projects on ethnology of religion and Roma issues. Her most important works are: $A$ gyimesi lakodalmak: Közös kultúra és különböző identitások? [Weddings in Gyimes: Common culture and particular identities?] Budapest, 2017. Conceptions of True Love and Love Magic among the Hungarians in Gyimes. In Begonya Enguix, Jordi Roca (eds.): Rethinking Romantic Love: Discussions, Imaginaries and Practices. Cambridge, 2015; Acculturation Processes among the Hungarians and Romanians in Gyimes: The Transformation of Communal Identities and Denominational Cultures. In Jonathan Gourlay, Gabriele Strohschen (eds.): Building Barriers and Bridges: Interculturalism in the $21^{\text {st }}$ Century. Oxford, 2014. E-mail: balatonyi.judit@gmail.com 